\title{
GROWTH AND YIELD OF COWPEA AS INFLUENCED BY DIFFERENT PHOSPHORUS LEVELS
}

\author{
F.B. Putul ${ }^{1}$, A.R. Khan ${ }^{1}$, M.S. Hossain ${ }^{1}$, A. Mahmud ${ }^{1}$, Q.A. Khaliq ${ }^{1}$ and T. Ahmed ${ }^{2}$ \\ ${ }^{1}$ Department of Agronomy and 2Department of Agroforestry and Environment, Bangabandhu Sheikh Mujibur \\ Rahman Agricultural University, Gazipur- 1706, Bangladesh. \\ Corresponding Email: arif@bsmrau.edu.bd
}

(Received: 15 January 2021, Accepted: 20 April 2021)

Keywords: Legume, triple super phosphate, absolute growth rate, quality

\begin{abstract}
The experiment was carried out at the research field of the Department of Agronomy of Bangabandhu Sheikh Mujibur Rahman Agricultural University (BSMRAU), Gazipur during December 2016 to April 2017 to investigate the effect of different phosphorus levels $\left(0,30,60\right.$ and $\left.90 \mathrm{~kg} \mathrm{P} \mathrm{ha}^{-1}\right)$ on the growth and yield of four selected cowpea genotypes (BARI Felon-1, A-06008, VI046192 and VI034386). The experiment was laid out in a factorial randomized complete block design with three replications. The results indicated that, among the genotype, BARI Felon-1 required minimum days to $1^{\text {st }}$ (96 DAS) and 50\% flowering (108 DAS) showing the highest absolute growth rate $\left(0.71 \mathrm{~g} \mathrm{day}^{-1}\right)$, crop growth rate (23.69 $\mathrm{g} \mathrm{m}^{-2}$ day $\left.{ }^{-1}\right)$, relative growth rate $\left(0.047 \mathrm{~g} \mathrm{~g}^{-1} \mathrm{day}^{-1}\right)$, net assimilation rate (1.40 $\mathrm{g} \mathrm{m}^{-2}$ day $\left.^{-1}\right)$, leaf area index (6.68), SPAD value (51.03), seed length $(0.71$ $\mathrm{cm})$ and breadth $(0.54 \mathrm{~cm})$. But the genotype, A-06008 gave the highest grain yield $\left(0.62 \mathrm{tha}^{-1}\right)$. Application of phosphorus at $90 \mathrm{~kg} \mathrm{ha}^{-1}$ showed the highest leaf area index (6.67), SPAD value $(50.98)$, pod length $(14.33 \mathrm{~cm})$, seed length $(0.70 \mathrm{~cm})$, seed breadth $(0.50 \mathrm{~cm})$ and grain yield $\left(0.34 \mathrm{t} \mathrm{ha}^{-1}\right)$. In terms of growth and yield, the cowpea genotype A-06008 showed the best performance at the phosphorus level of $90 \mathrm{~kg} \mathrm{ha}^{-1}$.
\end{abstract}

\section{Introduction}

Cowpea (Vigna unguiculata L. Walp) is an important legume-pulse crop grown around the world which serves food for human consumption and fodder for livestock (Mfeka et al., 2019). The ripe seed on an average contains $22 \%$ protein, $1.4 \%$ fat, $59.1 \%$ carbohydrate, and $3.7 \%$ ash. The energy value is $340 \mathrm{kcal} / 100 \mathrm{~g}$.

Cowpea is suitable to grow at all regions of Bangladesh and grown as a short-duration crop in the rice based cropping systems after the harvest of transplant aman rice (William, 2016). Cowpea production is lower which is mainly due to the poor agronomic management as adopted to its production. Although cowpea is known to obtain most of its nitrogen requirements through symbiotic fixation, cowpea requires more phosphorus $(P)$ than nitrogen (FAO, 2005). Basically, all legume crops need more $\mathrm{P}$ for growth and seed development (Sanginga et al., 2000). Phosphorus plays important role to cowpea yields as it stimulates growth, initiates nodule formation as well as accelerates the efficiency of the rhizobium-legume symbiosis (Haruna and Aliyu, 2011). Phosphorus stimulates root development and growth of young plants, giving them a good and vigorous start and control key enzyme reactions in the regulation of metabolic pathways. $\mathrm{P}$ favors increased leaf area and leaf area index by greater 
growth of the leaf blade (Abayomi et al., 2008). P inputs either from soil reserves or from added fertilizer based on successful production systems of legumes (Brynes and Bumb, 1998).

Acquisition of $\mathrm{P}$ fertilizer by crop depends on soil and plant properties. The research on genotypic variation of cowpea and the effect of $\mathrm{P}$ on the growth and development is little in Bangladesh. Therefore, this study was aimed to determine the effects of different levels of $P$ with genotypic variation on the growth and quality of four selected cowpea genotypes.

\section{Materials and Methods}

A field experiment was conducted at the Agronomy Research Field of Bangabandhu Sheikh Mujibur Rahman Agricultural University, Gazipur 1706 from December 2016 to April 2017. The experimental site is located in Madhupur Tract under Agro Ecological Zone (AEZ) 28 at geographic coordinate between 24 09' $\mathrm{N}$ latitude and 90 26' E longitude with an elevation of $8.4 \mathrm{~m}$ from the sea level. The experiment consisted of two factors viz. four cowpea genotypes i.e. BARI Felon- $1\left(\mathrm{G}_{1}\right)$, A-06008 $\left(\mathrm{G}_{2}\right)$, VI046192 $\left(\mathrm{G}_{3}\right)$ and $\mathrm{VI034386}\left(\mathrm{G}_{4}\right)$ and four levels of phosphorus like $\mathrm{P}_{0}\left(\right.$ no phosphorus i.e. control), $\mathrm{P}_{30}\left(30 \mathrm{~kg} \mathrm{P} \mathrm{ha}{ }^{-1}\right), \mathrm{P}_{60}\left(60 \mathrm{~kg} \mathrm{P} \mathrm{ha}{ }^{-1}\right)$ and $\mathrm{P}_{90}(90$ $\left.\mathrm{kg} \mathrm{P} \mathrm{ha}^{-1}\right)$. The experiment was laid out in a randomized complete block design (RCBD) with three replications. The unit plot size was $1.5 \mathrm{~m} \times 1.5 \mathrm{~m}$ with a planting configuration of 30 $\mathrm{cm} \times 10 \mathrm{~cm}$. A fertilizer dose of $30 \mathrm{~kg} \mathrm{~N}, 30 \mathrm{~kg} \mathrm{~K}, 10 \mathrm{~kg} \mathrm{~S}, 2 \mathrm{~kg} \mathrm{Zn}$ and $1 \mathrm{~kg} \mathrm{~B} \mathrm{ha}^{-1}$ (BARC, 2012) was applied as basal during final land preparation in the form of urea, muriate of potash (MoP), sulfur, zinc sulphate and boric acid, respectively. Different levels of phosphorus were applied as treatment in soil in the form of triple super phosphate (TSP). All fertilizers were applied during final land preparation. Seeds of similar size were sown after treating with Bavistin @ $2 \mathrm{~g} \mathrm{~kg}^{-1}$ of seeds. A light irrigation was provided immediately after sowing to ensure uniform emergence. Plant protection measures were taken and intercultural operations were done whenever necessary. Days to $1^{\text {st }}$ flower initiation and 50\% flowering from each plot were recorded. Soil Plant Analysis Development (SPAD) value of leaf was recorded from 3 plants in each plot at 120 DAS using a SPAD meter (model: SPA-502, Minolta Camera Co. Ltd. Japan). For growth estimation, sampling was done at 40, 60, 80, 100 and 120 DAS. At maturity, $1 \mathrm{~m}^{2}$ area excluding border was selected to record the agronomic parameters and yield. Ten sample pods and ten sample seeds were used to measure pod length, seed length and breadth. Grain yield was recorded and adjusted at $12 \%$ moisture content. Absolute growth rate (AGR), crop growth rate (CGR), relative growth rate (RGR), net assimilation rate (NAR) and leaf area index (LAI) were calculated using the following formulae:

$$
\begin{aligned}
\mathrm{AGR} & =\frac{\mathrm{W}_{2}-\mathrm{W}_{1}}{\mathrm{~T}_{2}-\mathrm{T}_{1}} \mathrm{~g} \text { day }^{-1} \\
\mathrm{CGR} & =\frac{\mathrm{W}_{2}-\mathrm{W}_{1}}{\mathrm{~T}_{2}-\mathrm{T}_{1}} \times \frac{1}{\mathrm{GA}} \mathrm{g} \text { day }^{-1} \\
\mathrm{RGR} & =\frac{1}{\mathrm{~W}_{1}} \times \frac{\mathrm{W}_{2}-\mathrm{W}_{1}}{\mathrm{~T}_{2}-\mathrm{T}_{1}}=\frac{\mathrm{LnW}_{2}-\mathrm{LnW}_{1}}{\mathrm{~T}_{2}-\mathrm{T}_{1}} \mathrm{gg}^{-1} \mathrm{day}^{-1} \\
\mathrm{NAR} & =\frac{\mathrm{LnL}_{2}-\mathrm{LnL}_{1}}{\mathrm{~L}_{2}-\mathrm{L}_{1}} \times \frac{\mathrm{W}_{2}-\mathrm{W}_{1}}{\mathrm{~T}_{2}-\mathrm{T}_{1}}=\mathrm{g} \mathrm{m}^{-2} \mathrm{day}^{-1}
\end{aligned}
$$




$$
\text { LAI }=\frac{\text { Surface area of leaf }}{\text { Groundarea }}
$$

Where, W1 = Dry weight at time T1 $(\mathrm{g}), \mathrm{W} 2=$ Dry weight at time T2 $(\mathrm{g}), \mathrm{GA}=$ Ground area $\left(\mathrm{m}^{2}\right)$, Ln $=\mathrm{Natural}$ logarithm, $\mathrm{L}_{1}=$ Leaf area at time $\mathrm{T}_{1}\left(\mathrm{~m}^{2}\right), \mathrm{L}_{2}=$ Leaf area at time $\mathrm{T}_{2}\left(\mathrm{~m}^{2}\right)$. The recorded data for different plant parameters were subjected to statistical analysis. Statistix 10 software program was used to perform analysis of variation. The treatment means were compared using the least significant difference (LSD) test at 5\% level of significance (Gomez and Gomez, 1984).

\section{Results and Discussion}

\section{Days to $1^{\text {st }}$ and $50 \%$ flowering}

Cowpea genotypes showed significant variation in number of days required to $1^{\text {st }}$ flower initiation. The genotype $\mathrm{G}_{4}$ took maximum time (99 DAS) and the genotype $\mathrm{G}_{1}$ required the lowest time (96 DAS) for $1^{\text {st }}$ flowering (Table 2). Phosphorus (P) fertilizer did not exert significant effect on days to $1^{\text {st }}$ flowering. However, the highest number of days to $1^{\text {st }}$ flowering (97 DAS) was obtained from $\mathrm{P}_{90}$ and the lowest (97 DAS) in $\mathrm{P}_{0}$ as presented in Table 2. Interaction between genotypes and $\mathrm{P}$ (Table 2 ) did not exert significant impact on days to $1^{\text {st }}$ flowering.

Days required to $50 \%$ flowering differed significantly in the genotypes tested. The maximum number of days required for $50 \%$ flowering (112 DAS) was observed in the genotype $\mathrm{G}_{4}$ and genotype $G_{1}$ needed significantly the lowest number of days (108 DAS) as presented in Table 2 . $\mathrm{P}$ fertilizer did not exert significant effect on days to $50 \%$ flowering (Table 2). The tested cowpea genotypes showed a marked variation in $1^{\text {st }}$ and $50 \%$ flowering. The variation in $1^{\text {st }}$ and $50 \%$ flowering is due to the inherent characters of the cowpea genotypes. Genotypic variation of flowering was also observed in common bean (Wondimu and Tana, 2017). Variation in $1^{\text {st }}$ and $50 \%$ flowering due to application of different levels of phosphorus has also been reported in cowpea (Ayodele and Oso, 2014; Nkaa et al., 2014).

\section{Absolute growth rate}

Absolute growth rate (AGR) showed a significant variation in the different cowpea genotypes tested. AGR in genotypes $G_{1}, G_{2}$ and $G_{4}$ increased progressively up to 100 DAS and in $\mathrm{G}_{3}$ reached a peak at 80 DAS after that those genotypes gradually decreased. AGR decreased as the plant matured because of cessation of vegetative growth and senescence of leaves and AGR was decreasing after 80 DAS in genotype $G_{3}$ and 100 DAS in genotypes $G_{1}, G_{2}$ and $G_{4}$. Among the genotypes, $\mathrm{G}_{1}$ registered a maximum AGR $\left(0.71 \mathrm{~g}\right.$ day $\left.^{-1}\right)$ and genotype $\mathrm{G}_{3}$ gave the lowest AGR (0.17 $\left.\mathrm{g} \mathrm{day}^{-1}\right)$ at 100 DAS (Fig. 1a).

Different $P$ levels significantly influenced the growth of cowpea. AGR increased gradually with time reaching a peak at 100 DAS and declined afterwards till 120 DAS regardless of the P levels. Plants treated with $\mathrm{P}_{60}$ showed the highest AGR $\left(0.56 \mathrm{~g}\right.$ day $\left.{ }^{-1}\right)$ and $\mathrm{P}_{0}$ gave the lowest AGR $\left(0.38 \mathrm{~g} \mathrm{day}^{-1}\right)$ at 100 DAS (Figure 2a). These results are in accordance with the findings of Seyed et al. (2011). The interaction of $\mathrm{G}_{3} \mathrm{P}_{90}$ gave the lowest $\left(-0.15 \mathrm{~g}\right.$ day $\left.{ }^{-1}\right)$ and $\mathrm{G}_{1} \mathrm{P}_{30}$ gave the highest AGR (0.95 $\left.\mathrm{g} \mathrm{day}^{-1}\right)$ at 100 DAS (Table 1$)$.

\section{Crop growth rate}

Crop growth rate (CGR) in different genotypes varied significantly as shown in Fig. 1b. CGR in genotypes $G_{1}, G_{2}$ and $G_{4}$ increased progressively up to 100 DAS and $G_{3}$ reached a peak at 80 DAS after that those genotypes gradually decreased (Fig. 1b). The highest CGR (23.69 $\mathrm{g} \mathrm{m}^{-2}$ 
day $^{-1}$ ) was obtained in the genotype $G_{1}$ and the lowest $\left(5.64 \mathrm{~g} \mathrm{~m}^{-2}\right.$ day $\left.^{-1}\right)$ in genotype $G_{3}$. Different $P$ levels significantly influenced the growth of cowpea. CGR increased gradually with time reaching a peak at 100 DAS and declined afterwards till 120 DAS regardless of the P levels. Similar result was reported that values of crop growth rate are normally low during early growth stages and increase with time, reaching maximum values at about the time of flowering (Fageria et al., 2006). Application of $\mathrm{P}$ enhanced leaf growth, reduced leaf senescence and helped intercept more radiation resulting in greater amount of photosynthesis. Among the levels of $\mathrm{P}, \mathrm{P}_{60}$ registered a maximum CGR $\left(18.56 \mathrm{~g} \mathrm{~m}^{-2}\right.$ day $\left.^{-1}\right)$ while $\mathrm{P}_{90}$ gave the lowest CGR (12.82 $\mathrm{g} \mathrm{m}^{-2}$ day $^{-1}$ ) at 100 DAS (Fig. 2b). Ehsan et al. (2017) also found the highest CGR applying $60 \mathrm{~kg} \mathrm{Pha}{ }^{-1}$ at all the growing period of mungbean. The interactions between genotypes and levels of $\mathrm{P}$ also showed significant variation in crop growth rate throughout the growing periods (Table 1). At 100 DAS the interaction of $\mathrm{G}_{1} \mathrm{P}_{30}$ gave the highest $\left(31.79 \mathrm{~g} \mathrm{~m}^{-2}\right.$ day $\left.^{-1}\right)$ and $\mathrm{G}_{3} \mathrm{P}_{60}$ gave significantly the lowest CGR $\left(3.14 \mathrm{~g} \mathrm{~m}^{-2}\right.$ day $\left.^{-1}\right)$.

\section{Relative growth rate}

The relative growth rate (RGR) gives the efficiency of current dry matter to produce future dry matter. RGR was high in early of the growth period and showed decreasing trend as the crop advanced in age (Fig. 1c). RGR decreases as the plant ages due to the fact that an increasing part of the plant is structural rather than metabolically active tissue and as such does not contribute to growth (Chattjrvedi et al., 1980). Among the genotypes tested, the highest RGR was $0.08 \mathrm{~g} \mathrm{~m}^{-2}$ day ${ }^{-1}$ in genotype $\mathrm{G}_{4}$ and the lowest in genotype $\mathrm{G}_{2}\left(0.05 \mathrm{~g} \mathrm{~g}^{-1}\right.$ day $\left.{ }^{-1}\right)$ at 60 DAS. The RGR was significantly influenced by different $P$ levels. However, irrespective of different P levels, RGR was pronounced early in the season and showed a decreasing trend as the crop advanced towards maturity (Fig. 2c). Similar decreasing trend of RGR was also reported by Ehsan et al. (2017) in mungbean. $P_{90}$ registered maximum RGR $\left(0.07 \mathrm{~g} \mathrm{~g}^{-1}\right.$ day $\left.^{-1}\right)$ while plants treated with $P_{0}$ gave the lowest RGR $\left(0.05 \mathrm{~g} \mathrm{~g}^{-1}\right.$ day $\left.{ }^{-1}\right)$ at 60 DAS in this study. Again, the interaction effect of genotypes and different levels of $P$ on RGR was found significant. The interaction of $G_{4} P_{90}$ gave the highest RGR $\left(0.09 \mathrm{~g} \mathrm{~g}^{-1}\right.$ day-1) and $G_{2} P_{0}$ gave the lowest $(0.01 \mathrm{~g}$ $\mathrm{g}^{-1}$ day $^{-1}$ ) at 60 DAS (Table 1$)$.

\section{Net assimilation rate}

Net assimilation rate (NAR) is a value that relates plant productivity to plant size. It is useful as a measure of the photosynthetic efficiency of plants and reflects the balance of photosynthetic rate against respiration and tissue loss rates (Quero et al., 2006). In the present study, different genotypes showed significant effect on NAR under different P levels (Fig.1d). NAR increased progressively from 60 DAS to 100 DAS after that the trend decreased in all the studied genotypes except $G_{3}$. NAR in the genotype $G_{3}$ increased gradually from 60 DAS to 80 DAS after that it decreased (Fig. 1d). At 100 DAS, the genotype $G_{1}$ gave the highest NAR $\left(4.10 \mathrm{~g} \mathrm{~m}^{-2}\right.$ day $\left.^{-1}\right)$ and $G_{3}$ genotype gave the lowest $\left(1.40 \mathrm{~g} \mathrm{~m}^{-2}\right.$ day ${ }^{-1}$. Different levels of $P$ showed significant effect on NAR. NAR increased progressively up to 100 DAS in all levels of P after that the trend decreased gradually (Fig. 2d). At 100 DAS, $\mathrm{P}_{60}$ gave the highest NAR $\left(3.54 \mathrm{~g} \mathrm{~m}^{-2}\right.$ day $\left.^{-1}\right)$ and $\mathrm{P}_{90}$ gave the lowest $\left(2.15 \mathrm{~g} \mathrm{~m}^{-2}\right.$ day $\left.{ }^{-1}\right)$. Likely, the interaction between genotypes and different $P$ levels showed significant impact on NAR. The interaction of $\mathrm{G}_{4} \mathrm{P}_{60}$ gave the highest (5.96 $\mathrm{g} \mathrm{m}^{-2}$ day $\left.^{-1}\right)$ and $\mathrm{G}_{3} \mathrm{P}_{60}$ gave the lowest $\left(0.75 \mathrm{~g} \mathrm{~m}^{-2}\right.$ day ${ }^{-1}$ ) NAR at 100 DAS (Table 1$)$. NAR decreased during the growing season as more and more leaves were fully or partially shaded. Also, the decrease in NAR with plant age may be due to older average leaf age which resulted in lower photosynthetic efficiency. 


\section{Leaf area index}

Leaf area index (LAI) depends on number of leaves and leaf expansion in a plant. Leaf area is made up of the total green area of emerged leaves (Keating and Carbery, 1993). It was indicated that leaf area index, leaf area duration and dry matter accumulation during the reproductive period strongly influence the yield components (Liu et al., 2004). Greater leaf area is necessary to have superior yield components in grain legumes (Muchow, 1985). Here, LAI increased progressively up to 100 DAS in all cowpea genotypes after that it gradually decreased (Fig. 1e). At 100 DAS, the highest LAI (6.68) was obtained in the genotype $G_{1}$ and the lowest (5.03) in genotype $G_{3}$. The variation in LAI among the genotypes might be due to genetic character of the genotypes.

\section{Greenness duration}

The greenness of different genotypes at 120 DAS was measured by SPAD meter. The highest SPAD value (51.03) was obtained in the genotype $G_{1}$ and the lowest (46.48) in $G_{3}$ (Fig. 1f). The general trend was an increase in SPAD value with the increase in $\mathrm{P}$ levels except in $\mathrm{P}_{60}$ though the variation wasn't significant. At 120 DAS, the highest SPAD value (50.98) was recorded at $\mathrm{P}_{90}$ and the lowest (47.19) at $\mathrm{P}_{60}$ (Fig. 2f). The interaction of genotypes and $\mathrm{P}$ levels did not exert significant impact on SPAD value of cowpea (Table 1). 


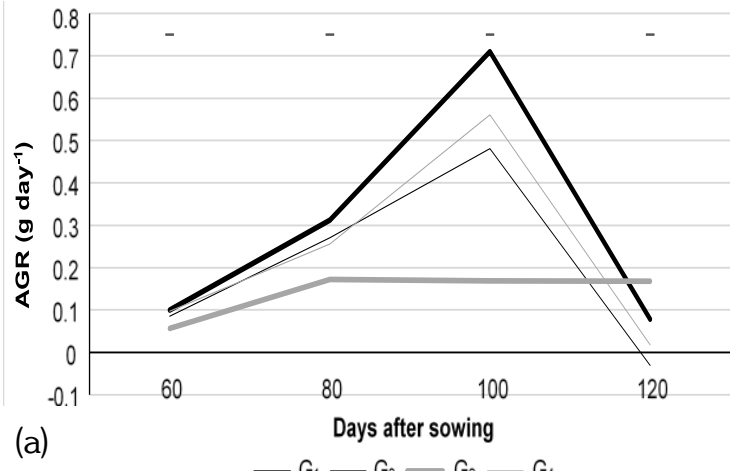

$-G_{1}-G_{2}-G_{3}-G_{4}$

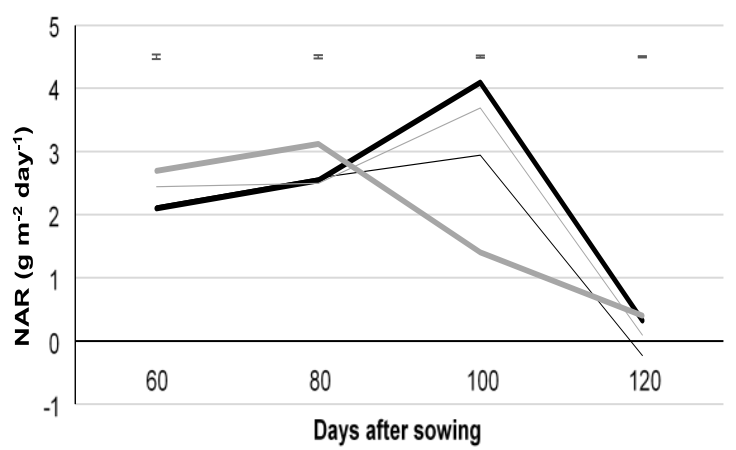

(d) (b)

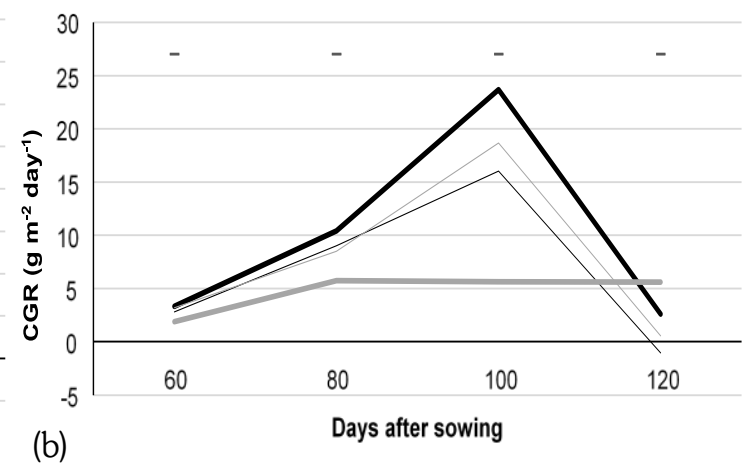

Days after sowing

$-G_{1}-G_{2}-G_{3}-G_{4}$

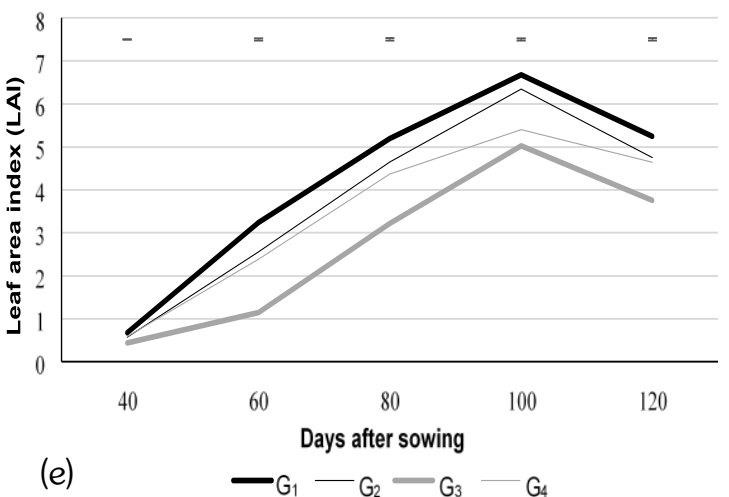

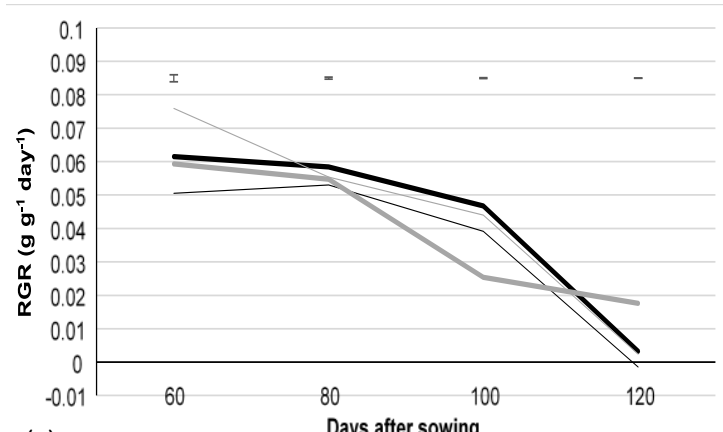

(c)

Days after sowing
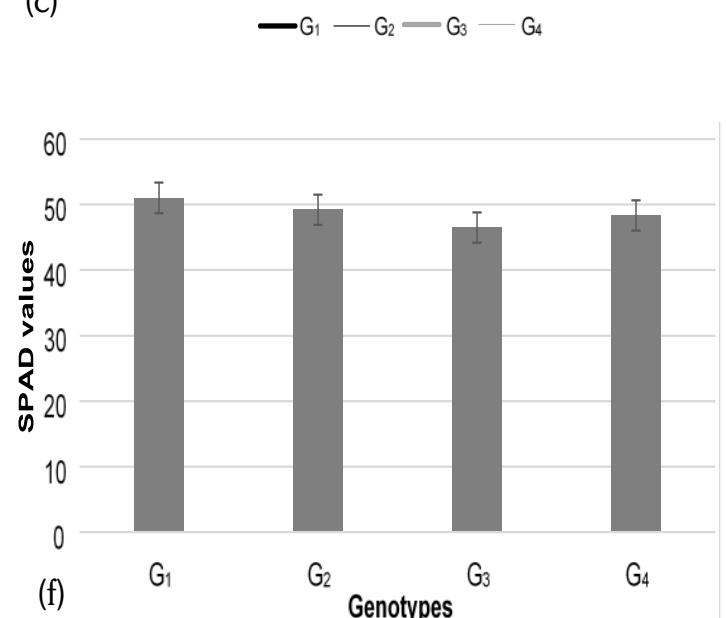

Fig. 1. Variation in (a) absolute growth rate (AGR), (b) crop growth rate (CGR), (c) relative growth rate (RGR), (d) net assimilation rate (NAR), (e) leaf area index (LAI) and (f) SPAD values of cowpea genotypes over time. Vertical bars indicate LSD $(0.05)$. 


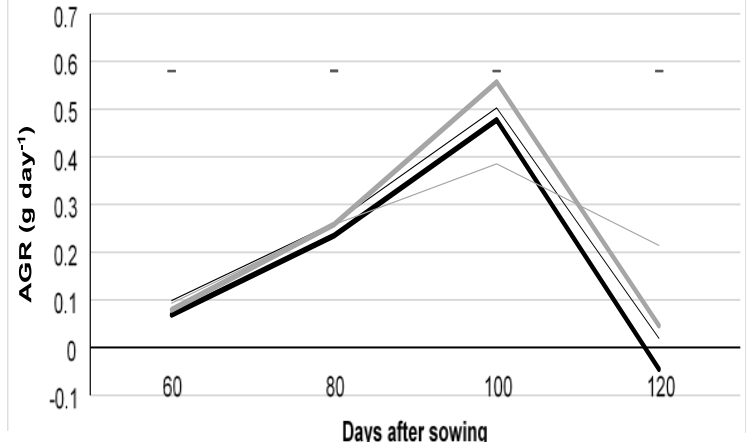

(a)

$$
-P_{0}-P_{30}-P_{60}-P_{90}
$$

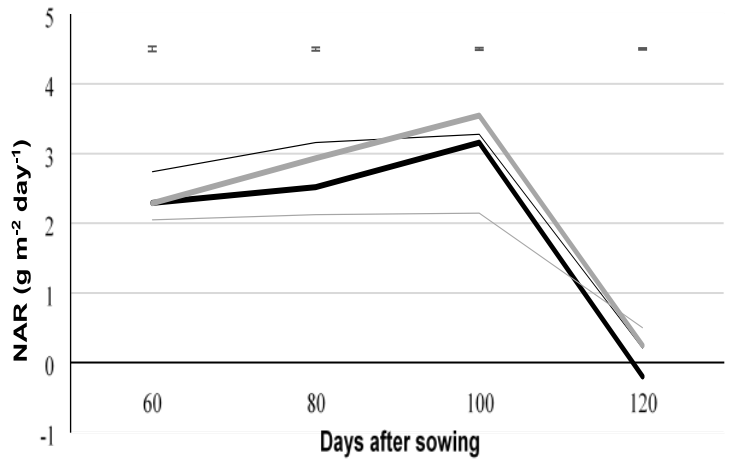

(d) (b)

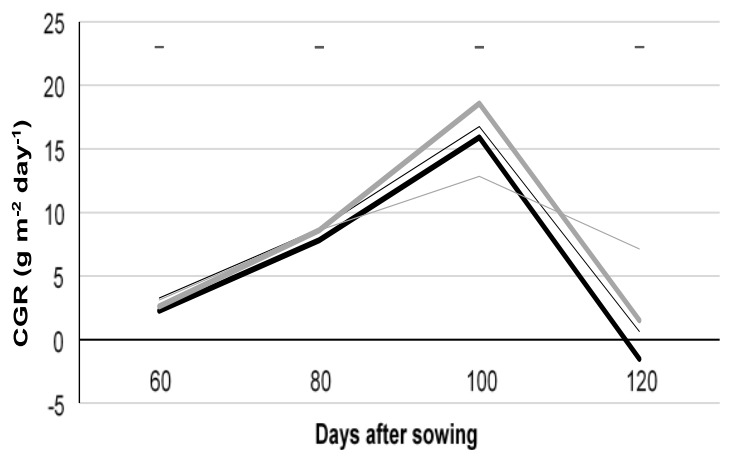

$-P_{0}-P_{30}-P_{60}-P_{90}$

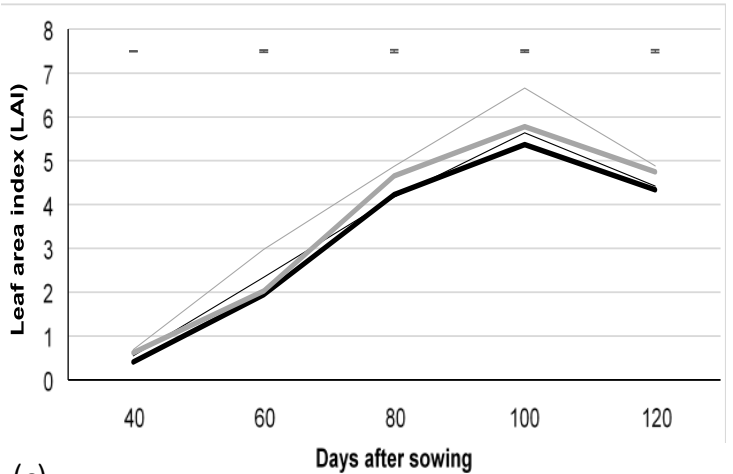

(e)

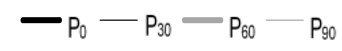

$-P_{0}-P_{30}-P_{60}-P_{90}$

Fig. 2. Variation in (a) absolute growth rate (AGR)

b) crop growth rate (CGR), (c) relative growth rate (RGR), (d) net assimilation rate (NAR) (e) leaf area index (LAI) and (f) SPAD values due to different levels of P over time in cowpea genotypes. Vertical bars indicate LSD (0.05).
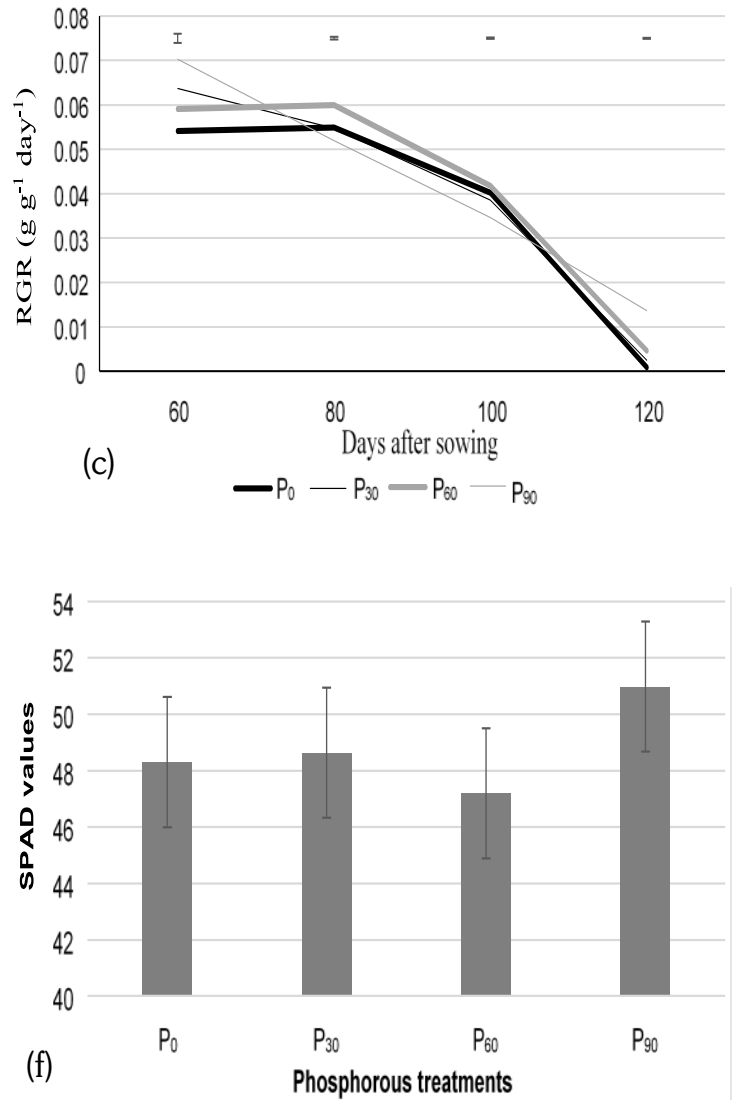
Table 1. Interaction effect of cowpea genotypes and levels of $\mathrm{P}$ on absolute growth rate (AGR), crop growth rate (CGR), relative growth rate (RGR), net assimilation rate (NAR), leaf area index (LAI) and SPAD value over time

\begin{tabular}{|c|c|c|c|c|c|c|c|c|c|c|c|c|c|c|c|c|c|c|c|c|c|c|}
\hline \multirow{2}{*}{$\begin{array}{l}\text { Interaction } \\
(\mathrm{G} \times \mathrm{P})\end{array}$} & \multicolumn{4}{|c|}{ AGR at different DAS } & \multicolumn{4}{|c|}{ CGR at different DAS } & \multicolumn{4}{|c|}{ RGR at different DAS } & \multicolumn{4}{|c|}{ NAR at different DAS } & \multicolumn{5}{|c|}{ LAI at different DAS } & \multirow{2}{*}{$\begin{array}{c}\begin{array}{c}\text { SPAD } \\
\text { value }\end{array} \\
120 \\
\end{array}$} \\
\hline & 60 & 30 & 00 & 20 & 60 & 80 & 100 & 120 & 60 & 00 & 100 & 120 & 60 & 00 & 100 & 250 & 40 & 60 & 80 & 00 & 20 & \\
\hline & .09 & & 74 & -0.25 & 3.06 & & & 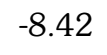 & 0.07 & & 05 & -0.01 & 2.36 & 3.05 & 3 & -1.63 & 0.48 & 2.76 & 4.73 & 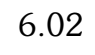 & 38 & 49.93 \\
\hline$P_{30}$ & 12 & 32 & 0.95 & -0.12 & 3.84 & .54 & 31.79 & -4.13 & 0.07 & 06 & 0.06 & 0.00 & 2.48 & .76 & 5.63 & -0.71 & 0.75 & 2.78 & 5.10 & .24 & 5.37 & 52.47 \\
\hline${ }_{1} P_{60}$ & 11 & 24 & 0.59 & 0.38 & 3.56 & 7.95 & 19.51 & 12.59 & 0.06 & 05 & 0.05 & 0.02 & 2.10 & 1.93 & 3.37 & 2.10 & 0.74 & 3.26 & 5.14 & 6.48 & 5.55 & 52.73 \\
\hline${ }_{1} \mathrm{P}_{90}$ & 09 & 36 & 0.56 & 0.31 & 2.86 & 12.01 & 1 & 10.41 & 0.05 & 07 & 0.04 & 0.01 & 1.46 & 2.43 & 2.74 & 1.54 & 0.72 & 4.17 & 5.80 & 7.97 & 5.69 & 56.21 \\
\hline $\mathrm{G}_{2} \mathrm{P}_{0}$ & 03 & 25 & 0.28 & 0.19 & 0.95 & 8.45 & 9 & 6.25 & 0.01 & 05 & 0.03 & 0.01 & 0.77 & 2.63 & 1.99 & 1.10 & 0.47 & 2.57 & 3.97 & 5.51 & 5.84 & 45.10 \\
\hline${ }_{2} \mathrm{P}_{30}$ & 13 & 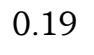 & 0.54 & -0.08 & 4.32 & .2 & 18 & -2.75 & 0.07 & 4 & 0.05 & 0.00 & 3. & 1.63 & 5 & -0.55 & 0.48 & 3.09 & 4.71 & $\epsilon$ & 4.03 & 49.87 \\
\hline $\mathrm{P}_{60}$ & & 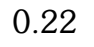 & 66 & 27 & 2.74 & 7.41 & & -9.01 & 0.06 & 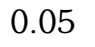 & 5 & -0.02 & 2 & 1 & 9 & 72 & 0.62 & 1 & 34 & 0 & 4.08 & 0.23 \\
\hline $\mathrm{G}_{2} \mathrm{P}_{90}$ & & 42 & 4 & 0.04 & 3.35 & 5 & 1 & 1.41 & 0.06 & 7 & 3 & 0 & 2.16 & 5 & 32 & 0.23 & 0.73 & 0 & 57 & 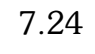 & 5.07 & 1.70 \\
\hline $\mathrm{G}_{3} \mathrm{P}_{0}$ & & & & 19 & 95 & & & 39 & 0.06 & 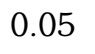 & 3 & 2 & 2.94 & 4 & 0 & 1.83 & 31 & 1.22 & 5 & 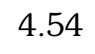 & 2.64 & 3.87 \\
\hline${ }_{3} \mathrm{P}_{30}$ & & & & 07 & 50 & 8.0 & & 2.35 & & & & 1 & 2.97 & & 7 & 49 & 39 & & 8 & & 46 & 20 \\
\hline$G_{1}$ & & & & 5 & 0 & 7.1 & & 8.41 & & & & 3 & 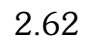 & & & 1.79 & 0.46 & & 3 & & 4.45 & 39.57 \\
\hline${ }_{3} \mathrm{P}_{90}$ & 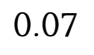 & 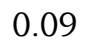 & 0 & 16 & 2.36 & 3.10 & . & 5.26 & 0.08 & $t$ & 0.03 & 0.02 & 2. & 9 & 1.20 & 1.21 & 0.57 & 1 & 3.21 & 5 & 3.45 & 49.30 \\
\hline & 9 & . & 73 & -0.31 & 3.16 & 6.87 & 24.18 & -10.30 & 0.08 & 0.05 & 0.06 & -0.02 & 3. & 2.05 & 2 & -2.09 & 0.40 & 2.07 & 5.07 & 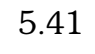 & 4.50 & 49.300 \\
\hline $\mathrm{G}_{4} \mathrm{P}_{30}$ & 0.10 & 0.30 & 0.25 & 0.21 & 3.46 & 9.94 & 8.22 & 7.09 & 0.08 & 0.06 & 0.02 & 0.01 & 2.42 & 2.97 & 1.86 & 1.61 & 0.58 & 2.87 & 3.88 & 5.02 & 3.84 & 44.00 \\
\hline $\mathrm{G}_{4} \mathrm{P}_{60}$ & .07 & 36 & 0.89 & -0.18 & 2.40 & 11.93 & 29.63 & -5.89 & 0.06 & 0.07 & 0.05 & -0.01 & 1.92 & 3.62 & 5.96 & -1.18 & 0.66 & 2.13 & 4.83 & 5.12 & 4.91 & 46.23 \\
\hline $\mathrm{G}_{4} \mathrm{P}_{90}$ & 0.12 & 0.16 & 0.38 & 0.34 & 3.86 & 5.34 & 12.75 & 11.44 & 0.09 & 0.04 & 0.04 & 0.02 & 2.33 & 1.34 & 2.33 & 2.01 & 0.72 & 3.18 & 4.93 & 6.05 & 5.33 & 53.93 \\
\hline & 0.00 & 0.00 & 0.00 & 0.00 & 0.10 & 0.14 & 0.13 & 0.10 & 0.00 & 0.00 & 0.00 & 0.00 & 0.13 & 0.10 & 0.07 & 0.05 & 0.02 & 0.09 & 0.13 & .11 & 0.13 & NS \\
\hline CV (\%) & 2.09 & 0.99 & 0.47 & 3.05 & 2.09 & 0.99 & 0.47 & 3.05 & 4.02 & 1.31 & 0.83 & 2.40 & 3.44 & 2.24 & 1.43 & 7.42 & 1.56 & 2.36 & 1.71 & 1.08 & 1.65 & 11.37 \\
\hline
\end{tabular}

DAS = Days after sowing 
Different levels of P significantly influenced the LAI (Fig. 2e). Regardless of the levels of P, LAI increased progressively up to 100 DAS in all P treatments after that it gradually decreased (Fig. 2e). Plants treated with $P_{90}$ showed the highest LAI (6.67) and $P_{0}$ showed the lowest (5.37) at 100 DAS. Variation in LAI due to the application of different levels of P in cowpea was also reported in several studies (Ayodele and Oso, 2014; Nkaa et al., 2014). The interaction effect of genotypes and levels of $\mathrm{P}$ was also significant on LAI throughout the growth period (Table 1). At 100 DAS the best interaction was $G_{1} P_{90}$ which gave the highest (7.97) and $G_{3} P_{0}$ gave the lowest (4.54) LAI. Increase in LAI due to increasing rate of applied P might be attributed to welldeveloped root system of the genotypes favored by $\mathrm{P}$ uptake. These findings were also supported by the results found in soybean (Singh and Bansal, 2000).

\section{Pod length}

Pod length was significantly influenced by the variation in genotypes and different levels of $\mathrm{P}$. The longest pod $(18.31 \mathrm{~cm})$ was recorded in genotype $\mathrm{G}_{4}$ and the shortest $(8.59 \mathrm{~cm})$ in $\mathrm{G}_{3}$ (Table 2). Application of different levels of $\mathrm{P}$ showed significant influence on pod length. The $\mathrm{P}_{90}$ had the longest pod $(14.33 \mathrm{~cm})$ and $\mathrm{P}_{30}$ had the shortest $(13.94 \mathrm{~cm})$ as presented in Table 10. Nkaa et al. (2014) also showed an increasing pod length due to $\mathrm{P}$ application in cowpea. The interaction of genotypes and different levels of $\mathrm{P}$ showed significant impact on pod length. The highest pod length $(19.1 \mathrm{~cm})$ was measured from the $\mathrm{G}_{4} \mathrm{P}_{30}$ interaction and the shortest $\left(7.78 \mathrm{~cm}\right.$ ) from $\mathrm{G}_{3} \mathrm{P}_{30}$ (Table 2).

\section{Seed length and breadth}

Seed length and breadth in cowpea genotypes varied significantly as shown in Table 2. The average highest seed length and breadth $(0.71 \mathrm{~cm}$ and $0.54 \mathrm{~cm}$, respectively) were obtained in the genotype $G_{1}$ and the lowest in $G_{3}(0.62 \mathrm{~cm}$ and $0.43 \mathrm{~cm}$, respectively). Application of different levels of $\mathrm{P}$ also showed significant influence on seed length and breadth. The average lowest seed length and breadth $\left(0.67 \mathrm{~cm}\right.$ and $0.47 \mathrm{~cm}$, respectively) were obtained in $\mathrm{P}_{0}$ and the highest $\left(0.70 \mathrm{~cm}\right.$ and $0.50 \mathrm{~cm}$, respectively) in $\mathrm{P}_{60}$ and $\mathrm{P}_{90}$ (Table 2). The interaction between genotypes and levels of $\mathrm{P}$ showed significant effect on seed length and breadth (Table 2). The $\mathrm{G}_{1} \mathrm{P}_{60}$ interaction gave the highest seed length and breadth $(0.77 \mathrm{~cm}$ and $0.60 \mathrm{~cm}$, respectively) and $\mathrm{G}_{3} \mathrm{P}_{0}, \mathrm{G}_{3} \mathrm{P}_{30}$ and $\mathrm{G}_{3} \mathrm{P}_{60}$ had the lowest $(0.60 \mathrm{~cm}$ and $0.40 \mathrm{~cm}$, respectively).

\section{Grain yield}

Both genotypes and $\mathrm{P}$ levels exerted significant influence on grain yield. Genotypic variations in grain yields were evident (Table 2). The genotype $\mathrm{G}_{2}$ gave significantly the highest grain yield $\left(0.62 \mathrm{t} \mathrm{ha}^{-1}\right)$ and $\mathrm{G}_{4}$ gave the lowest $\left(0.03 \mathrm{t} \mathrm{ha}^{-1}\right)$. Grain yield also increased significantly with increasing level of $\mathrm{P} . \mathrm{P}_{0}$ obtained the lowest $\left(0.27 \mathrm{t} \mathrm{ha}^{-1}\right)$ and $\mathrm{P}_{90}$ obtained the highest $(0.34$ $t \mathrm{t} \mathrm{h}^{-1}$ ) grain yield (Table 2). Moreover, the interaction of genotypes and different $\mathrm{P}$ levels exerted significant effect on grain yield (Table 2). $\mathrm{G}_{2} \mathrm{P}_{90}$ gave the highest grain yield $\left(0.69 \mathrm{t} \mathrm{ha}^{-1}\right)$ and $\mathrm{G}_{4} \mathrm{P}_{30}$ gave the lowest $\left(0.01 \mathrm{t} \mathrm{ha}^{-1}\right)$. The tested cowpea genotypes varied significantly in their grain yield though different $P$ levels exerted significant influence on it. Grain yield increased with the increasing level of $P$. This might be due to the fact that $\mathrm{P}_{90}$ contributed to the highest NAR, LAI, greenness duration, pod length, seed length and breadth. These results are in accordance with the findings obtained by Nkaa et al. (2014) and Singh et al. (2011). 
Table 2. Days to $1^{\text {st }}$ flowering, days to $50 \%$ flowering, pod length, seed length, seed breadth and grain yield of cowpea genotypes as influenced by different levels of $\mathrm{P}$

\begin{tabular}{|c|c|c|c|c|c|c|}
\hline $\begin{array}{l}\text { Genotypes } \\
\text { (G) }\end{array}$ & $\begin{array}{l}\text { Days to } 1^{\text {st }} \\
\text { flowering } \\
\text { (DAS) }\end{array}$ & $\begin{array}{l}\text { Days to } 50 \% \\
\text { flowering } \\
\text { (DAS) }\end{array}$ & $\begin{array}{l}\text { Pod } \\
\text { length } \\
\text { (cm) }\end{array}$ & $\begin{array}{l}\text { Seed } \\
\text { length } \\
(\mathrm{cm})\end{array}$ & $\begin{array}{c}\text { Seed } \\
\text { breadth } \\
(\mathrm{cm})\end{array}$ & $\begin{array}{l}\text { Grain } \\
\text { yield } \\
\left(\mathrm{t} \mathrm{ha}^{-1}\right)\end{array}$ \\
\hline $\mathrm{G}_{1}$ & 95.67 & 107.75 & 14.83 & 0.71 & 0.54 & 0.51 \\
\hline $\mathrm{G}_{2}$ & 96.67 & 108.50 & 14.70 & 0.70 & 0.50 & 0.62 \\
\hline $\mathrm{G}_{3}$ & 97.67 & 109.08 & 8.59 & 0.62 & 0.43 & 0.04 \\
\hline $\mathrm{G}_{4}$ & 99.25 & 112.08 & 18.31 & 0.70 & 0.50 & 0.03 \\
\hline $\operatorname{LSD}_{(0.05)}$ & 0.44 & 0.73 & 1.00 & 0.02 & 0.02 & 0.01 \\
\hline CV $(\%)$ & 0.55 & 0.80 & 8.89 & 3.87 & 5.87 & 3.32 \\
\hline $\begin{array}{l}\text { Phosphorus } \\
\text { (P kg ha-1) }^{-1}\end{array}$ & $\begin{array}{l}\text { Days to } 1^{\text {st }} \\
\text { flowering } \\
\text { (DAS) }\end{array}$ & $\begin{array}{c}\text { Days to } 50 \% \\
\text { flowering } \\
\text { (DAS) }\end{array}$ & $\begin{array}{l}\text { Pod } \\
\text { length } \\
\text { (cm) }\end{array}$ & $\begin{array}{l}\text { Seed } \\
\text { length } \\
\text { (cm) }\end{array}$ & $\begin{array}{l}\text { Seed } \\
\text { breadth } \\
\text { (cm) }\end{array}$ & $\begin{array}{l}\text { Grain } \\
\text { yield } \\
\left(\mathrm{t} \mathrm{ha} \mathrm{h}^{-1}\right)\end{array}$ \\
\hline $\mathrm{P}_{0}$ & 97.17 & 109.08 & 14.02 & 0.67 & 0.47 & 0.27 \\
\hline$P_{30}$ & 97.22 & 109.50 & 14.13 & 0.68 & 0.50 & 0.28 \\
\hline$P_{60}$ & 97.25 & 109.33 & 13.9 & 0.70 & 0.50 & 0.32 \\
\hline $\mathrm{P}_{90}$ & 97.42 & 109.50 & 14.33 & 0.70 & 0.50 & 0.34 \\
\hline $\operatorname{LSD}_{(0.05)}$ & NS & NS & 1.04 & 0.02 & 0.02 & 0.01 \\
\hline CV $(\%)$ & 0.55 & 0.80 & 11.84 & 3.87 & 5.87 & 3.32 \\
\hline $\begin{array}{l}\text { Interaction } \\
\text { (G P) }\end{array}$ & $\begin{array}{l}\text { Days to 1st } \\
\text { flowering } \\
\text { (DAS) }\end{array}$ & $\begin{array}{l}\text { Days to } 50 \% \\
\text { flowering } \\
\text { (DAS) }\end{array}$ & $\begin{array}{l}\text { Pod } \\
\text { length } \\
\text { (cm) }\end{array}$ & $\begin{array}{l}\text { Seed } \\
\text { length } \\
(\mathrm{cm})\end{array}$ & $\begin{array}{c}\text { Seed } \\
\text { breadth } \\
\text { (cm) }\end{array}$ & $\begin{array}{l}\text { Grain } \\
\text { yield } \\
\left(\mathrm{t} \mathrm{ha}^{-1}\right)\end{array}$ \\
\hline $\mathrm{G}_{1} \mathrm{P}_{0}$ & 95.67 & 107.67 & 14.80 & 0.67 & 0.47 & 0.39 \\
\hline $\mathrm{G}_{1} \mathrm{P}_{30}$ & 95.67 & 108.00 & 15.62 & 0.72 & 0.60 & 0.59 \\
\hline $\mathrm{G}_{1} \mathrm{P}_{60}$ & 95.67 & 107.67 & 14.19 & 0.77 & 0.60 & 0.49 \\
\hline $\mathrm{G}_{1} \mathrm{P}_{90}$ & 95.67 & 107.67 & 14.72 & 0.70 & 0.50 & 0.56 \\
\hline $\mathrm{G}_{2} \mathrm{P}_{0}$ & 96.67 & 108.00 & 14.55 & 0.70 & 0.50 & 0.65 \\
\hline $\mathrm{G}_{2} \mathrm{P}_{30}$ & 97.00 & 109.00 & 14.04 & 0.70 & 0.50 & 0.49 \\
\hline $\mathrm{G}_{2} \mathrm{P}_{60}$ & 96.33 & 108.33 & 14.89 & 0.70 & 0.50 & 0.67 \\
\hline $\mathrm{G}_{2} \mathrm{P}_{90}$ & 96.67 & 108.67 & 15.31 & 0.70 & 0.50 & 0.69 \\
\hline $\mathrm{G}_{3} \mathrm{P}_{0}$ & 97.33 & 109.00 & 8.68 & 0.60 & 0.40 & 0.03 \\
\hline $\mathrm{G}_{3} \mathrm{P}_{30}$ & 97.67 & 108.67 & 7.78 & 0.60 & 0.40 & 0.02 \\
\hline $\mathrm{G}_{3} \mathrm{P}_{60}$ & 97.67 & 109.00 & 8.42 & 0.60 & 0.40 & 0.09 \\
\hline $\mathrm{G}_{3} \mathrm{P}_{90}$ & 98.00 & 109.67 & 9.46 & 0.67 & 0.50 & 0.04 \\
\hline $\mathrm{G}_{4} \mathrm{P}_{0}$ & 99.00 & 111.67 & 18.1 & 0.70 & 0.50 & 0.02 \\
\hline $\mathrm{G}_{4} \mathrm{P}_{30}$ & 99.33 & 112.33 & 19.1 & 0.70 & 0.50 & 0.01 \\
\hline $\mathrm{G}_{4} \mathrm{P}_{60}$ & 99.33 & 112.33 & 18.25 & 0.70 & 0.50 & 0.03 \\
\hline $\mathrm{G}_{4} \mathrm{P}_{90}$ & 99.33 & 112.00 & 17.83 & 0.70 & 0.50 & 0.08 \\
\hline $\operatorname{LSD}_{(0.05)}$ & NS & NS & 2.09 & 0.04 & 0.05 & 0.02 \\
\hline CV (\%) & 0.55 & 0.80 & 11.84 & 3.87 & 5.87 & 3.32 \\
\hline
\end{tabular}

\section{Conclusions}

Growth and quality parameters of four cowpea genotypes in response to four phosphorus fertilizer application levels were evaluated. Growth and quality of cowpea were influenced by different phosphorus levels though genotypic variation was conspicuous. The results revealed that among the four selected cowpea genotypes, the highest absolute growth rate, crop growth rate, relative growth rate, leaf area index, greenness duration and seed length and breadth were obtained from BARI Felon-1, but the genotype A-06008 gave the highest grain yield $(0.62 \mathrm{t}$ $\mathrm{ha}^{-1}$ ). Plants with phosphorus $90 \mathrm{~kg} \mathrm{ha}^{-1}$ gave the highest leaf area index, greenness duration, 
pod length, seed length, breadth and grain yield $\left(0.34 \mathrm{t} \mathrm{ha}^{-1}\right)$. The genotype A-06008 gave the highest grain yield $\left(0.69 \mathrm{t} \mathrm{ha}^{-1}\right)$ at $\mathrm{P} 90 \mathrm{~kg} \mathrm{ha}^{-1}$.

\section{References}

Abayomi, Y.A., T.V. Ajibade, O.F. Sammuel and B.F. Sa'adudeen. 2008. Growth and yield responses of cowpea (Vignaunguiculata (L.) Walp) genotypes to nitrogen fertilizer (N) application in the Southern Guinea Savanna zone of Nigeria. Asian J. Plant Sci. 7(2): 170176.

Ayodele, O.J. and A.A. Oso. 2014. Cowpea responses to phosphorus fertilizer application at AdoEkiti, South-West Nigeria. J. Appl. Sci. Agric. 9(2): 485-489.

BARC (Bangladesh Agricultural Research Council). 2012. Fertilizer Recommendation Guide, Bangladesh Agricultural Research Council, Farmgate, Dhaka 1215, p.274.

Biswas, P.K., J.U. Ahmed, R.R. Saha and G.S. Torofder. 1996. Response of different nitrogen levels on nodulation, dry matter and seed yield in cowpea genotypes. Bangladesh J. Agric. Res. 21(1): 75-79.

Brynes, B.H. and B.L. Bumb. 1998. Population growth, food production and nutrient requirements in nutrient use in crop production. Ed. Z. Rengel. Food Product Press, New York, London.

Chattjrvedi, G.S., P.K. Aggarwal and S.K. Sinha. 1980. Growth and yield of determinate and indeterminate cowpeas in dry land agriculture. J. Agric. Sci., Camb. 94: 137-144.

Dugje, I.Y., L.O. Omoigai, F. Ekeleme, A.Y. Karama and H. Ajeigbe. 2009. Farmer's guide to cowpea production in West Africa. IITA, Ibadan, Nigeria, p.20.

Ehsan, Q., D.S. Rana, and A.K. Choudhary. 2017. Effect of crop establishment methods and phosphorus nutrition on growth and productivity of mungbean (Vigna radiata L. Wilczek) in semi-arid Afghanistan. Ann. Agric. Sci. 38(2): 200-207.

Fageria, N.K., V.C. Ballgar and R. Clark. 2006. Physiology of Crop Production. Haworth Press Inc. pp.23-56.

FAO (Food and Agriculture Organization). 2005. Cowpea production database for Nigeria 19902004. http://www.faostat.fao.org/.

Gomez, K.A. and A.A. Gomez. 1984. Statistical procedures for agricultural research, Second edition, John Wiley and Sons Inc., New York.

Haruna, I.M. and L. Aliyu. 2011. Yield and economic returns of sesame (Sesamum indicum L.) as influenced by poultry manure, nitrogen and phosphorus at Samaru, Nigeria. Elixir Agric. 39: 4884-4887.

Keating, B.A. and P.S. Carbery. 1993. Resources capture and use in intercropping solar radiation. Field Crops Res. 34: 273-301.

Langyintuo, A.S., J. Lowenberg-DeBoer, M. Faye, D. Lamber and G. Ibro. 2003. Cowpea supply and demand in West Africa. Field Crops Res. 82: 215-231.

Liu, X., J. Jin, S.H. Herbert, Q. Zhang and G. Wang. 2004. Yield components, dry matter, leaf area index and leaf area duration of soybean in northeast China. Chinese Academy of Sciences. Field Crops Res. 93(1): 85-89.

Mfeka, N., R.A. Mulidzi and F.B. Lewu. 2019. Growth and yield parameters of three cowpea (Vigna unguiculata L. Walp) lines as affected by planting date and zinc application rate. S. Afr. J. Sci. 115(12): 1-9.

Muchow, R.C. 1985. Analysis of the effects of water deficits on grain legumes grown in a semi-arid tropical environment in terms of radiation, interception and its efficiency of use. Field Crops Res. 11(4): 309-323. 
Nkaa, F.A., O.W. Nwokeocha and O. Ihuoma. 2014. Effect of phosphorus fertilizer on growth and yield of cowpea (Vignaunguiculata). J. Pharm. Biol. Sci. 9(5):74-82.

Quero, J.L., R. Villar, T. Marañón, R. Zamora, D.B. Vegaand L.D. Sack. 2006. Relating leaf photosynthetic rate to whole-plant growth: drought and shade effects on seedlings of four Quercus species. Funct. Plant Biol. 35:725-737.

Sanginga, N., O. Lyasse and B.B. Singh. 2000. Phosphorus use efficiency and nitrogen balance of cowpea breeding lines in a low $\mathrm{P}$ soil of the derived savanna zone in West Africa. Plant Soil. 220: 119-128.

Seyed, A.V. and A.F. Hossein. 2011. Mycorrhizal fungi influence on physiological growth indices in basil induced by phosphorus fertilizer under irrigation deficit conditions. World Acad. Sci. Eng. Technol. 59: 2182-2184.

Singh, A., A.L. Baoule, H.G. Ahmed, A.U. Dikko, U. Aliyul, M.B. Sokoto, J. Alhassan, M. Musa and B. Haliru. 2011. Influence of phosphorus on the performance of cowpea (Vigna unguiculata L. Walp.) varieties in the Sudan savanna of Nigeria. Agric. Sci. 2(3): 313-317.

Singh, S.P. and K.N. Bansal. 2000. Response of soybean (Glycinemax) to nitrogen, its application time and sulphur. Indian J. Agric. Sci. 70(1): 34-36.

William, E. 2016. Introduction of short duration pulses into rice-based cropping systems in western Bangladesh. Australian Center for International Agricultural Research. Australian Government.

Wondimu, W. and T. Tana. 2017. Yield response of common bean (Phaseolus vulgaris L.) varieties to combined application of nitrogen and phosphorus fertilizers at Mechara, Eastern Ethiopia. J. Plant Biol. Soil Health. 4(2): 7. 